\title{
DISCONNECTED, THOUGH SATISFIED: PPHUBBING BEHAVIOR AND RELATIONSHIP SATISFACTION
}

\author{
Esra CİZMECİ \\ Termal Vocational College, Yalova University, Yalova, Turkey \\ esra.cizmeci@yalova.edu.tr
}

\begin{abstract}
Mobile phones are the primary communication tools in every person's daily lives. As they started including the Internet and so let many applications to work in people's pockets, they became the tools of something more than communication, the tools of managing lives. However, besides easing many routines of daily lives, frequent use of these devices raised questions about whether they damage interpersonal communication, or not. Phubbing is the act when mobile devices lead people to ignore the ones beside them, and so cut the interpersonal communication. When this act is performed among couples of intimate relationships, this behavior is named as 'partner phubbing' (pphubbing). Studies found that by cutting the communication among romantic couples, by causing feelings of being ignored, and by raising doubt and jealousy, partner phubbing decreases relationship satisfaction. Accordingly, this study aims to compare perceived partner phubbing and the relationship satisfaction of people who are dating, and people who are currently married in Turkey. With a sample of 500 participants and being the first study conducted to measure the impact of partner phubbing on relationship satisfaction in Turkey, throughout a survey consisting of two scales (Pphubbing Scale and Relationship Satisfaction Scale) this study found that phubbing behavior is prevalently performed among couples in Turkey as well. However, results demonstrate that pphubbing behavior does not negatively impact the relationship satisfaction of couples in Turkey, the possible reasons of which are discussed.
\end{abstract}

Keywords: Partner Phubbing, Relationship Satisfaction, Dating, Married Couples, Interpersonal Communication

\section{ILETIŞIMSİ, AMA MUTLU: TEKNOLOJIYLE MEŞGUL OLUP PARTNERLE ILGILENMEME DAVRANIŞININ TÜRKIYYE'DEKİ FLÖRT EDEN VE EVLİ ÇIFTLERİN İLISSKİ MEMNUNIYYETLERİ ÜZERİNDEKİ ETKİSİ}

\begin{abstract}
ÖZ
Mobil telefonlar, her insanın gündelik yaşamının birincil iletişim aracı konumunda. İnternet kullanımı ile birlikte insanlara ceplerinde birçok uygulamayı taşıyabilme imkanı sunan günümüz cep telefonları artık iletişim kurmaktan daha fazlasının, hayatı yönetmenin amacı olarak kullanılıyor. Ancak bu cihazlar bir yandan yaşamları kolaylaştırırken, diğer yandan aşırı kullanımlarıyla kişiler arası iletişimi aksatıp aksatmadıklarıyla ilgili soruların belirmesine yol açıyorlar. Teknolojiyle meşgul olup yanındakiyle ilgilenmemek (phubbing), kişiler arası iletişimi aksatan bir eylem olarak beliriyor. $\mathrm{Bu}$ davranış çiftler arasında yapıldığında, adına teknolojiyle meşgul olup partnerle ilgilenmeme (partner phubbing) deniyor. Yapılan çalışmalara göre bu davranış duygusal ilişki içerisindeki çiftlerin iletişimini kopararak, partnerlerinin kendileriyle ilgilenmediği hissiyatına girerek, ayrıca da şüphe ve kıskançlık duygularını ortaya çıkararak ilişki memnuniyetinin düşmesine sebep oluyor. Bununla ilgili olarak, bu çalışmanın amacı Türkiye'de bulunan flört eden ve evli olan çiftlerin algıladıkları partnerle ilgilenmeme davranışı ve ilişki memnuniyetlerini karşılaştırmaktır. Bu konuda Türkiye'de yapılan ilk çalışma olarak bu makalede 500 katılımcı iki farklı ölçekten (Pphubbing Ölçeği ve İlişki Memnuniyet Ölçeği) oluşan anketler doldurmuştur. Çalışma soncuunda, teknoloji sebebiyle partnerle ilgilenmeme davranışının Türkiye'deki çiftler arasında oldukça yaygın olduğu, ancak bu davranışın çiftlerin ilişkilerinden memnuniyetleri üzerinde olumsuz bir etki oluşturmadığı bilgisi elde edilmiştir.
\end{abstract}


Anahtar Kelimeler: Partnerle İlgilenmeme, İlişki Memnuniyeti, Flört, Evli Çiftler, Kişilerarası İleitşim

\section{INTRODUCTION}

Since mobile phones invaded daily lives, their use has turned into a habit of continual checking. As the two most significant technologies that have changed lives of the people, cell phones and the Internet came together and functioned perfectly on smartphones, increasing the frequency of mobile phone usage more and more. With the help of the Internet, smartphones function like small computers that one can carry anywhere, anytime. They are the main devices to go online now and with them, people go online more than they did with their computers (Ofcom, 2015). Reading the news, answering endless text-messages, checking e-mails or social media accounts are only some of the habitual activities offered by smartphones to their users, leading to a gradually increasing mobile phone usage. Touching every aspect of people's daily lives, these mobile technologies have not skipped close interpersonal relationships. Apart from facilitating those relationships, the focus is gradually on the fact that they can also ruin them. Research has proven that the use of technology can have significant impacts on intimate relationships (Henline, 2006; Hertlein, 2012; Hertlein \& Blumer, 2014). Although studies on specifically the impact of smartphone use in couple relations are quite rare, there are a few in the literature (e.g. Coyne et al., 2011; McCormack, 2015).

According to the studies, when technology is used by couples to spend quality times together, it improves the relationship (Henline, 2006). However, when it is used individually, studies (Abeele, Schouten, \& Antheunis, 2015; Krasnova, Abramova, Notter, \& Baumann, 2016; Roberts \& David, 2016) found that it decreases relationship satisfaction.

This individual usage of mobile phones in presence of someone else is called as "phubbing". Phubbing is a word created by the words of "phone snubbing", and it means looking at one's mobile phone instead of communicating with the ones actually beside them (Karadağ et al., 2015: 60). When phubbing behavior is considered for intimate couple relationships, it is right to call it as "partner phubbing". Therefore, partner phubbing (Pphubbing) means phubbing in the presence of the spouse or a romantic partner (Roberts \& David, 2016: 134). In relation to this concept, the present research investigates if partner phubbing has an impact on the relationship satisfaction of Turkish dating couples and married couples.

\section{LITERATURE REVIEW}

A literature search on relationship satisfaction, mobile phone use, social media use, and phubbing behavior was conducted. There is no study in Turkey specifically focusing on the impact of partner phubbing on couples in Turkey. These studies are:

\section{- $\quad$ Relationship Satisfaction}

'Satisfaction' in romantic relationships means an intrapersonal evaluation and feelings of a person about their partner and the relationship (Sakalli-Ugurlu, 2003: 294). Related literature suggests that relationship satisfaction can be achieved only when partners fulfill each other's needs and desires (Peleg, 2008: 388). More importantly, a healthy communication among partners is crucial for relationship satisfaction (Eğeci \& Gençöz, 2006). To be able to feel connected, partners should be open and focused for each other by avoiding any distractions (Leggett \& Rossouw, 2014: 49). In relation with that, it is found that the distractions caused by the presence of mobile phones decrease the quality of intimate relationships (Przybylski \& Weinstein, 2012; Roberts \& David, 2016).

\section{- $\quad$ Partner Phubbing}

Studies (McDaniel \& Coyne, 2014; Coyne, Stockdale, Busby, Iverson, \& Grant, 2011; Lenhart \& Duggan, 2014) demonstrate that phubbing takes place often among partners. As mentioned before, partner phubbing (Pphubbing) means phubbing in the presence of the spouse or a romantic partner (Roberts \& David, 2016: 134). A significant point to consider is that, smartphones are increasingly known to be related to the usage of social networking sites (Perez, 2015; Smith, 2015), and so they 
raise the feeling of jealousy, because they have functions of threatening social interactions with other people. Many studies (Clayton, Nagurney, \& Smith, 2013; Darvell, Walsh, \& White, 2011; Drouin, M., Miller, D.A., \& Dibble, J.L., 2014; Elphinston \& Noller, 2011; McCormack, 2015; Muise, Christofides, \& Desmarais, 2009; Utz \& Beukeboom, 2011) prove that the use of networking websites (which work on smartphones) like Facebook are highly related to jealousy, cheating, and relationship satisfaction. Thus, partner phubbing is also claimed to be important not because the other partner feels ignored, but because they feel threatened (Krasnova, Abramova, Notter, \& Baumann, 2016: 5).

\section{- $\quad$ Social Media Addiction and Phubbing}

Karadağ et al. (2015) found that social media addiction has a great effect on phubbing behavior, and this is also related to the Internet addiction since social media functions through the Internet connection. Smartphone addiction is also seen as similar to the Internet addiction (Mok et al., 2014). This is related to the fact that what differentiates smartphones from old-style mobile phones is that the use of their applications require an Internet connection, therefore users can do everything they do on the internet with their smartphones. Internet and smartphone addiction are also directly related to "the fear of missing out" (Przybylski, Murayama, DeHaan, \& Gladwell, 2013). Not to miss out what is going on in social media may also cause people to ignore their actual company in a social setting (Chotpitayasunondh, \& Douglas, 2016: 10). As most of the studies reveal, the Internet addiction (Cao \& Su, 2007; Johansson \& Götestam, 2004; Kim, Ryu, Chon, Yeun, Choi, Seo, \& Nam, 2006; Park, Kim, \& Cho, 2008; Tsai \& Lin, 2003), smartphone addiction (Choi, Lee, \& Ha, 2012; Kim, Lee, Lee, Nam, \& Chung, 2014; Kwon, Kim, Cho, \& Yang, 2013; Park \& Lee, 2014) and mobile addiction (Balakrishnan \& Raj, 2012; Ling, 2007; Walsh, White, \& Young, 2008) are all known mostly with young people. For this reason, it is hypothesized (H1) that young people will declare more perception of pphubbing behavior.

\section{- $\quad$ Relationship Satisfaction for Married Couples}

Moreover, marriage is a type of relationship that is harder to end because of legal and children-related issues even if there is dissatisfaction among couples. For this reason, some counseling programs (Bagarozzi et al., 1984) are measured and developed to educate dating/arranged couples for the upcoming responsibilities of marriage. Dating couples on the other hand, seem to have less binding responsibilities than married couples, therefore, it makes sense for them to not maintain an unsatisfactory relationship. Therefore, in this study, it is hypothesized (H2) that non-married people will declare more relationship satisfaction than married ones.

\section{- $\quad$ Mobile Phones, Pphubbing and Relationships}

More importantly, there are many researches implemented to understand how cell phones (Coyne, Stockdale, Busby, Iverson, \& Grant, 2011; Duran, Kelly \& Rotaru, 2011; Miller-Ott, Kelly \& Duran, 2012; Wei \& Lo, 2006) and mobile phones (Hall, Baym, \& Miltner, 2014; Horstmanshof \& Power, 2005; Jin \& Pena, 2010; Vincent, 2006) affect their users' romantic relationships. Some studies (McDaniel, 2016; Nazir \& Pişkin, 2016; Roberts \& David, 2016) specifically found that phubbing behavior damages romantic relationships in terms of causing conflicts, decreasing relationship satisfaction, and individual well-being. Therefore, in this study it is hypothesized (H3) that as pphubbing behavior increases, relationship satisfaction will decrease.

\section{METHODOLOGY}

An online survey was created from the Partner Phubbing Scale of Roberts \& David (2015), and the Relationship Assessment Scale of Hendrick (1988). The survey had 21 items in total, including 5 demographic questions (of age, sex, marital status, education, and relationship duration).

A "phubber" is someone who ignores their company by focusing on their cell phone, and a "phubbee" is someone who gets ignored by their company's cell phone use (Roberts \& David, 2016). It should be pointed out here that, in the pphubbing scale, questions are asked to phubbees, therefore expecting them to answer by considering the phubbing behavior of their partner.

Participants were selected via snowball sampling $(\mathrm{N}=500)$ from people either in a romantic relationship, or married. 238 of the participants were female, whereas 262 were male. $36,6 \%$ of the 
participants were 25 years old or younger, 43,2\% were between the ages of 26-35, 13,6 \% were between 36-45, and 6,6\% were 46 years old or older. 207 participants were married, 293 were nonmarried. $48,8 \%$ of the participants were with university education. And finally, $43,8 \%$ of the participants were having a relationship/marriage of 5-10 years.

In obtaining findings and analysis of the survey data, descriptive statistics are calculated. Exploratory Factor Analysis (EFA) and Confirmatory Factor Analysis (CFA) are applied to data. Also, the fit index is measured. Moreover, Cronbach's Alpha coefficient is calculated to find the relaibility of the scale. In comparisons of demographic variables, T-Test is applied to compare two independent groups, whereas ANOVA Test is applied to compare more than two groups. After the ANOVA Test, LSD Test is applied as a subsidiary to find differences. Regression analysis is applied to determine the impact of Pphubbing behavior on Relationship Satisfaction. Findings are evaluated in 95\% reliability interval, and 5\% meaningfulness level.

\section{RESULTS}

Findings of this study are as shown below:

Table 1: Demographic variables

\begin{tabular}{|c|c|c|c|}
\hline \multicolumn{2}{|l|}{ Variables } & Frequency & Percentage \\
\hline \multirow{3}{*}{ Sex } & Female & 238 & 47,6 \\
\hline & Male & 262 & 52,4 \\
\hline & Total & 500 & 100,0 \\
\hline \multirow{4}{*}{ Age } & \begin{tabular}{|ll}
25 & and \\
Younger & \\
\end{tabular} & 183 & 36,6 \\
\hline & $26-35$ & 216 & 43,2 \\
\hline & 36 and Older & 101 & 20,2 \\
\hline & Total & 500 & 100,0 \\
\hline \multirow{3}{*}{ Marital Status } & Non-married & 293 & 58,6 \\
\hline & Married & 207 & 41,4 \\
\hline & Total & 500 & 100,0 \\
\hline \multirow{4}{*}{ Education } & High School & 86 & 17,2 \\
\hline & $\begin{array}{l}\text { Associate } \\
\text { Degree }\end{array}$ & 244 & 48,8 \\
\hline & $\begin{array}{l}\text { Undergraduate } \\
\text { and Higher }\end{array}$ & 170 & 34,0 \\
\hline & Total & 500 & 100,0 \\
\hline \multirow{4}{*}{$\begin{array}{lr}\text { Length } & \text { of } \\
\text { Relationship/Marriage }\end{array}$} & 1-5 Years & 203 & 40,6 \\
\hline & 6-10 Years & 219 & 43,8 \\
\hline & $\begin{array}{l}11 \text { Years and } \\
\text { more }\end{array}$ & 78 & 15,6 \\
\hline & Total & 500 & 100,0 \\
\hline
\end{tabular}

Demographic variables of participants (distribution of frequency and percentage) are shown in Table 1.

Table 2: Exploratory factor analysis of pphubbing scale

\begin{tabular}{|l|c|}
\hline Items & Factor Loading \\
\hline $\begin{array}{l}\text { B6-During leisure time that my partner and I are able to spend together, } \\
\text { my partner uses his/her cell phone. }\end{array}$ & 0.86 \\
\hline B8-My partner uses his or her cell phone when we are out together. & 0.83 \\
\hline
\end{tabular}




\begin{tabular}{|l|c|}
$\begin{array}{l}\text { B9-If there is a lull in our conversation, my partner will check his or her } \\
\text { cell phone. }\end{array}$ & 0.78 \\
\hline $\begin{array}{l}\text { B3-My partner keeps his or her cell phone in their hand when he or she } \\
\text { is with me. }\end{array}$ & 0.76 \\
\hline $\begin{array}{l}\text { B4-When my partner's cell phone ring sor beeps, he/she pulls it out even } \\
\text { if we are in the middle of a conversation. }\end{array}$ & 0.74 \\
\hline $\begin{array}{l}\text { B1-During a typical mealtime that my partner and I spend together, my } \\
\text { partner pulls out and checks his/her cell phone. }\end{array}$ & 0.72 \\
\hline $\begin{array}{l}\text { B5-My partner glances at his/her cell phone when talking to me. } \\
\text { B2-My partner places his or her cell phone where they can see it when } \\
\text { we are together. }\end{array}$ & 0.71 \\
\hline B7-My partner does not uses his or her phone when we are talking. & 0.66 \\
\hline
\end{tabular}

KMO and Bartlett tests are applied to be able to detect if the scale is suitable for Factor Analysis. As a result of these tests, KMO value is found 0.91 meaningful, and Bartlett Test is found $(p<0.01)$ meaningful. Accordingly, it is seen that the set of data used fits Factor Analysis, that there is high correlation, and Factor Analysis can be done for this part. Results of the Exploratory Factor Analysis are shown in Table 2. Expressions in this part have are gathered under a single factor consisting of 9 items, which has $53.80 \%$ explained variance.

Figure 1: Confirmative factor analysis of pphubbing behavior scale

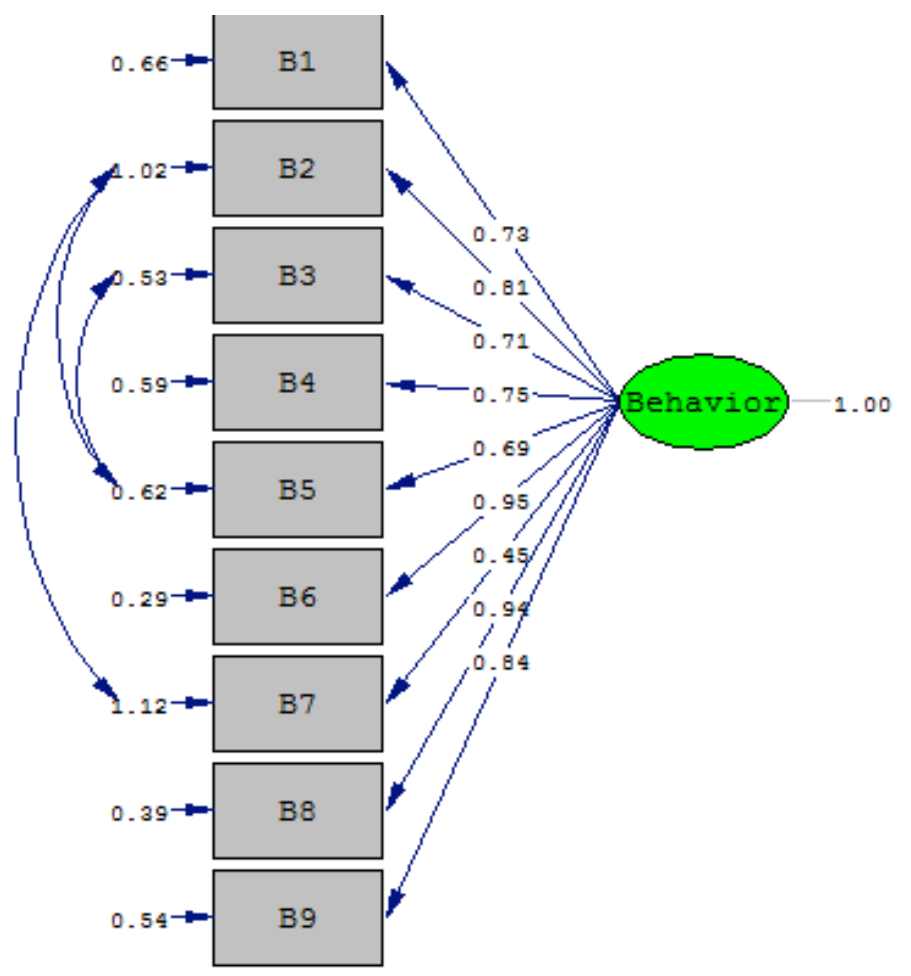

Next, Confirmatory Factor Analysis is applied to be able to evaluate if the 9-item and single factor structure of the Pphubbing behavior scale is valid. Fit indexes and the suitability of the model are examined according to the results of the analysis. Following the evaluations, modification recommendations are examined. Then, modifications are made in relation to recommendations. The model obtained is shown in Figure 1. As seen in Figure 1, the scale consists of 9 items. Fit indexes found $\mathrm{X}^{2} / \mathrm{df}=3.48, \mathrm{GFI}=0.96, \mathrm{AGFI}=0.93, \mathrm{NFI}=0.98, \mathrm{NNFI}=0.98, \mathrm{IFI}=0.99, \mathrm{CFI}=0.99$, RMSEA=0.07. 
According to these results, fit indexes are adequate. Therefore, data gathered are fit with the single factor structure of the original scale. Cronbach's Alpha coefficient which was calculated to determine the relaibility of the scale is found as 0.89 . This shows that internal consistency and reliability of the scale are high.

Table 3: Exploratory factor analysis of the relationship satisfaction scale

\begin{tabular}{|l|l|}
\hline Items & Factor Loading \\
\hline S2-In general, how satisfied are you with your relationship? & 0.85 \\
\hline S3-How good is your relationship compared to most? & 0.80 \\
\hline S1-How well does your partner meet your needs? & 0.75 \\
\hline S4-How often do you wish you hadn't gotten into this relationship? & 0.74 \\
\hline S5-To what extent has your relationship met your original expectation? & 0.62 \\
\hline
\end{tabular}

KMO and Bartlett tests have been applied to check if the scale fits Factor Analysis. As a result, KMO value is found to be 0.83 , and Bartlett test is found to be $(\mathrm{p}<0.01)$ meaningful. With regards to these results, it is decided that the data set is suitable for Factor analysis, that there is a high correlation among variables, and Factor Analysis can be applied fort his part. Results of Exploratory Factor Analysis are shown in Table 3. Expressions derived from the Factor Analysis are gathered under a single factor consisting of a total descriptive variance of $56.91 \%$, and 5 items.

Figure 2: Confirmative Factor Analysis of the Relationship Satisfaction Scale

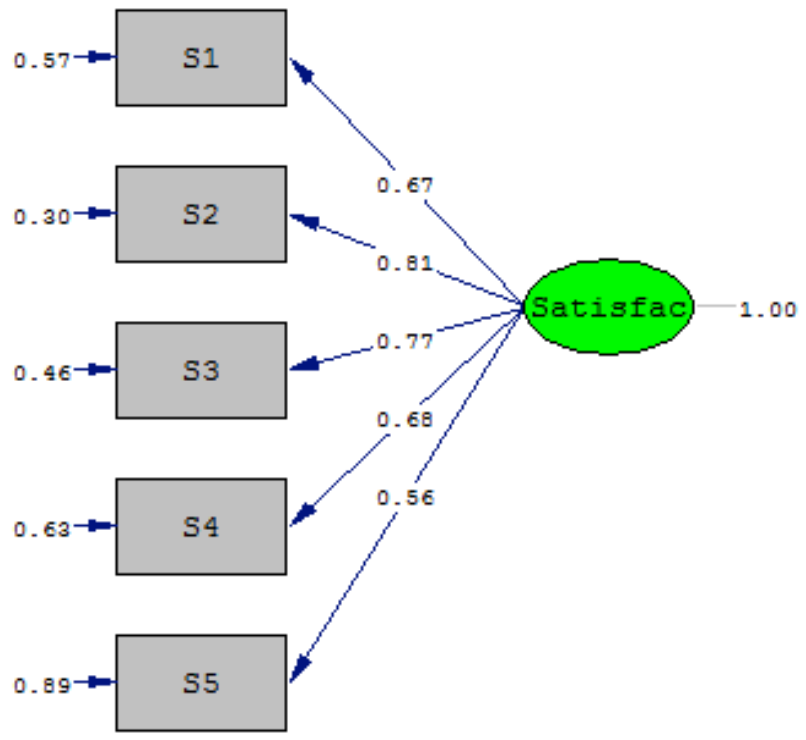

Next, Confirmative Factor Analysis is applied to evaluate if the single factor and 5-item structure of the Relationship Satisfaction Scale is confirmed, or not. The model obtained is shown in Figure 2. The figure shows that the scale has 5 items. Fit indexes are found as $X^{2} / \mathrm{df}=0.50, \mathrm{GFI}=1$, AGFI $=0.99$, $\mathrm{NFI}=1, \mathrm{NNFI}=1, \mathrm{IFI}=1, \mathrm{CFI}=1, \mathrm{RMSEA}=0.00$. These results show that fit indexes are adequate. Accordingly, it is decided that the single factor structure of the original scale fits with the gathered data. The Cronbach's Alpha coefficient which is calculated to check the reliability of the scale is found 0.80 . Therefore, it is seen that the internal consistency and reliability of the scale is high.

Table 4: Descriptive statistics

\begin{tabular}{|l|l|l|l|l|l|}
\hline Variables & N & Mean & $\begin{array}{l}\text { Std. } \\
\text { Deviation }\end{array}$ & Skewness & Kurtosis \\
\hline $\begin{array}{l}\text { Pphubbing } \\
\text { Behavior }\end{array}$ & 500 & 2.47 & 0.81 & -0.11 & -0.01 \\
\hline $\begin{array}{l}\text { Relationship } \\
\text { Satisfaction }\end{array}$ & 500 & 3.48 & 0.77 & 0.15 & -0.03 \\
\hline
\end{tabular}


Table 4 indicates that participants perceive pphubbing behavior on average, and they are highly satisfied with their relationships.

Table 5: T test results of the comparisons

\begin{tabular}{|c|c|c|c|c|c|c|c|}
\hline \multicolumn{3}{|l|}{ Variables } & $\mathbf{N}$ & Mean & $\begin{array}{l}\text { Std. } \\
\text { Deviation }\end{array}$ & $\mathbf{t}$ & p \\
\hline \multirow{4}{*}{ Sex } & \multirow{2}{*}{$\begin{array}{l}\text { Pphubbing } \\
\text { Behavior }\end{array}$} & Female & 238 & 2.56 & 0.81 & \multirow{2}{*}{2.50} & \multirow{2}{*}{0.01} \\
\hline & & Male & 262 & 2.38 & 0.80 & & \\
\hline & \multirow{2}{*}{$\begin{array}{l}\text { Relationship } \\
\text { Satisfaction }\end{array}$} & Female & 238 & 3.67 & 0.84 & \multirow{2}{*}{5.29} & \multirow{2}{*}{0.00} \\
\hline & & Male & 262 & 3.31 & 0.67 & & \\
\hline \multirow{4}{*}{ Marital Status } & \multirow{2}{*}{$\begin{array}{l}\text { Pphubbing } \\
\text { Behavior }\end{array}$} & \begin{tabular}{|l|} 
Non- \\
married
\end{tabular} & 293 & 2.41 & 0.74 & \multirow[t]{2}{*}{-1.72} & \multirow{2}{*}{0.09} \\
\hline & & Married & 207 & 2.54 & 0.88 & & \\
\hline & \multirow{2}{*}{$\begin{array}{l}\text { Relationship } \\
\text { Satisfaction }\end{array}$} & \begin{tabular}{|l|}
$\begin{array}{l}\text { Non- } \\
\text { married }\end{array}$ \\
\end{tabular} & 293 & 3.45 & 0.81 & \multirow[t]{2}{*}{-1.11} & \multirow[t]{2}{*}{0.27} \\
\hline & & Married & 207 & 3.53 & 0.71 & & \\
\hline
\end{tabular}

Table 5 first shows the comparison of participants' pphubbing behavior perception and relationship satisfaction with regards to sex. Both the perception of pphubbing behavior and relationship satisfaction reveal meaningful differences $(p<0,05)$. Differences show that female participants both perceive more pphubbing behavior from their partners, and also they declare more relationship satisfaction.

Table 6: ANOVA test results of the comparisons

\begin{tabular}{|c|c|c|c|c|c|c|c|c|}
\hline \multicolumn{3}{|l|}{ Variables } & \multirow{2}{*}{$\begin{array}{l}\mathbf{N} \\
183 \\
\end{array}$} & \multirow{2}{*}{$\begin{array}{l}\text { Mean } \\
2.53 \\
\end{array}$} & \multirow{2}{*}{\begin{tabular}{|l|}
$\begin{array}{l}\text { Std. } \\
\text { Deviation }\end{array}$ \\
0.73 \\
\end{tabular}} & \multirow{4}{*}{$\begin{array}{l}\text { F } \\
0.87\end{array}$} & \multirow{4}{*}{\begin{tabular}{|l} 
Sig. \\
0.42
\end{tabular}} & \multirow{4}{*}{ Fark } \\
\hline \multirow{6}{*}{ Age Groups } & \multirow{3}{*}{$\begin{array}{l}\text { Pphubbing } \\
\text { Behavior }\end{array}$} & A-25 and Younger & & & & & & \\
\hline & & B-26-35 & 216 & 2.43 & 0.78 & & & \\
\hline & & C-36 and Older & 101 & 2.43 & 0.98 & & & \\
\hline & \multirow{3}{*}{$\begin{array}{l}\text { Relationship } \\
\text { Satisfaction }\end{array}$} & A-25 and Under & 183 & 3.64 & 0.85 & \multirow{3}{*}{5.76} & \multirow{3}{*}{0.00} & \multirow{3}{*}{$\begin{array}{l}\mathbf{A}>\mathbf{B}, \\
\mathbf{A}>\mathbf{C}\end{array}$} \\
\hline & & B-26-35 & 216 & 3.39 & 0.73 & & & \\
\hline & & C-36 and Older & 101 & 3.42 & 0.66 & & & \\
\hline \multirow{6}{*}{ Education } & \multirow{3}{*}{$\begin{array}{l}\text { Pphubbing } \\
\text { Behavior }\end{array}$} & A-High School & 86 & 2.21 & 0.98 & \multirow{3}{*}{9.92} & \multirow{3}{*}{0.00} & \multirow{3}{*}{$\begin{array}{l}\mathbf{C}>\mathbf{A}, \\
\mathbf{C}>\mathbf{B}, \\
\mathbf{B}>\mathbf{A}\end{array}$} \\
\hline & & B-Associate Degree & 244 & 2.43 & 0.75 & & & \\
\hline & & \begin{tabular}{|l|} 
C-Undergraduate and \\
Higher \\
\end{tabular} & 170 & 2.66 & 0.74 & & & \\
\hline & \multirow{3}{*}{$\begin{array}{l}\text { Relationship } \\
\text { Satisfaction }\end{array}$} & A-High School & 86 & 3.50 & 0.80 & \multirow{3}{*}{7.93} & \multirow{3}{*}{0.00} & \multirow{3}{*}{$\mathbf{C}>\mathbf{B}$} \\
\hline & & B-Associate Degree & 244 & 3.36 & 0.71 & & & \\
\hline & & \begin{tabular}{|l|} 
C-Undergraduate and \\
Higher
\end{tabular} & 170 & 3.66 & 0.82 & & & \\
\hline \multirow{6}{*}{$\begin{array}{l}\text { Length of } \\
\text { Relationship }\end{array}$} & \multirow{3}{*}{$\begin{array}{l}\text { Pphubbing } \\
\text { Behavior }\end{array}$} & A-1-5 Years & 203 & 2.56 & 0.72 & \multirow{3}{*}{2.42} & \multirow{3}{*}{0.09} & \\
\hline & & B-6-10 Years & 219 & 2.42 & 0.80 & & & \\
\hline & & C-11 Years and More & 78 & 2.37 & 1.00 & & & \\
\hline & \multirow{3}{*}{$\begin{array}{l}\text { Relationship } \\
\text { Satisfaction }\end{array}$} & A-1-5 Years & 203 & 3.74 & 0.86 & \multirow{3}{*}{20.99} & \multirow{3}{*}{0.00} & \multirow{3}{*}{$\begin{array}{l}\mathbf{A}>\mathbf{B}, \\
\mathbf{A}>\mathbf{C}\end{array}$} \\
\hline & & B-6-10 Years & 219 & 3.27 & 0.64 & & & \\
\hline & & C-11 Years and More & 78 & 3.42 & 0.69 & & & \\
\hline
\end{tabular}


Table 6 shows the comparison of participants' perceptions of pphubbing behavior and relationship satisfaction with regards to age groups. The perception of pphubing behavior does not reveal any statistically meaningful difference $(p>0,05)$ with regards to age groups. However, relationship satisfaction of participants reveals statistically meaningful difference $(p<0,05)$. Results suggest that participants at the ages of 25 or younger are more satisfied with their relationships in comparison to other age groups.

Also, education level of participants reveals differences $(p<0,05)$ in both their perception of behavior and relationship satisfaction levels. Results suggest that as the education level increases, perception of pphubbing behavior and relationship satisfaction decreases.

Moreover, length of relationship duration does not reveal any statistically meaningful differences $(p>0,05)$ in terms of the perception of pphubbing behavior, whereas it reveals differences $(p<0,05)$ in terms os relationship satisfaction. As the length of relationship duration increases, perception of pphubbing behavior increases, and relationship satisfaction decreases.

Table 7: Impact of pphubbing behavior on relationship satisfaction

\begin{tabular}{|l|l|l|l|}
\hline Independent Variable & B & t & Sig. \\
\hline (Constant) & 3.040 & 27.747 & .000 \\
\hline Pphubbing behavior & .180 & 4.262 & .000 \\
\hline & $\mathrm{R}^{2}=$ & & 0.035 \\
& $\mathrm{~F}=$ & & 18.162 \\
& Sig. $=0.000$ & & \\
& & & \\
& & & \\
\end{tabular}

Dependent Variable: Relationship Satisfaction

Results of the Regression Analysis in Table 7 demonstrate that Pphubbing behavior has positive impact $(\beta=0.180, t=4.262, \mathrm{p}<0.05)$ on Relationship Satisfaction. Pphubbing behavior describes 3,5\% of the change $\left(\mathrm{R}^{2}=0.035\right)$ in Relationship Satisfaction. Accordingly, it is found that perceived Pphubbing behavior has little but positive impact on Relationship Satisfaction.

\section{DISCUSSION}

Following Roberts \& David's (2016) study on the correlation between pphubbing and relationship satisfaction, this research found very significant results in terms of revealing the differences about the impact of pphubbing behavior on relationship satisfaction of couples in Turkey. It is also the first study of pphubbing from Turkey.

First of all, it is found in this study that female participants (Table 5) both perceive more pphubbing behavior from their partners, and also ironically they declare more relationship satisfaction. SakalliUgurlu (2003) highlights in her study that because non-married women are more future-oriented in their relationship plans especially in Turkey, they tend to report more relationship satisfaction than males. In spite of any problems, they also work harder to maintain their relationships. Therefore, this can be a culture-based explanation for why non-married female participants in this study both reported that they felt more phubbing, and also that they are more satisfied with their relationships than male participants.

Moreover, we found (Table 6) that, as the length of relationship duration increases, perception of pphubbing behavior increases, and relationship satisfaction decreases. Other studies (Dush, Taylor, \& Kroeger, 2008) also found that couples in longer relationships declare less satisfaction. Accordingly, participants at the ages of 25 or younger (Table 6) in the current study declared more satisfaction with their relationships in comparison to other age groups. 
Furthermore, we hypothesized (H1) that since young people are perceived to use new media technologies more in their daily lives, they would report more perceived pphubbing behavior. However, the results (Table 6) found no meaningful differences in terms of age in reporting pphubbing, therefore hypothesis 1 (H1) is rejected. This result could explained by the possibility that people from all ages use their mobile phones in an increasing rate each day, and phubbing has become a common and a prevalent and socially acceptable act performed by everyone (Chotpitayasunondh \& Douglas, 2016: 16).

According to the results of the study, overall, married participants (Table 5) declared a little bit more satisfaction than non-married participants, which rejects our hypothesis $2(\mathrm{H} 2)$. The reason that Turkish married couples declare that they are satisfied with their relationships could be the meaning given to the institution of "marriage" in Turkey. Islamic traditions in Turkey count marriage as a sacred institution, in which satisfaction and maintenance of the marriage are public expectations as one gets married (Hünler \& Gençöz, 2005). Although family structure has changed since the establishment of the Turkish Republic, and divorce rates are increasing in Turkey like it is the case around the world, marriage and family are still sacred and so Turkish participants may not want to admit that they are in an unsatisfactory marriage.

In accordance with that, the most unexpected result of the study is that the perceived pphubbing behavior seemed to have a little, but a positive impact (Table 7) on relationship satisfaction, contradicting and rejecting hypothesis 3 (H3). Although most studies (McDaniel, 2016; Nazir \& Pişkin; Przybylski \& Weinstein, 2012; Roberts \& David, 2016) found that pphubbing behavior decreases relationship satisfaction, the current study found the opposite. This finding may have a few explanations. Servies (2012: 16) found that distractions of technological devices do not have negative impacts on the relationship satisfaction of romantic couples. From a different perspective, Hall, Baym, \& Miltner (2014: 137) argue that those who apply to the relationship norms and who are satisfied with their relationship do not enact pphubbing behavior to their partners.

However, pphubbing seems to be like an inevitable act, independent from the satisfaction of a relationship. People experience pphubbing, but they are also pphubbers, so this can be an explanation why participants in this study both felt that they were being pphubbed and they were also satisfied with their relationships. As mentioned before, when people see phubbing behavior happening frequently around them by most of the people, they start to perceive it as socially acceptable (Chotpitayasunondh \& Douglas, 2016: 16). Therefore, it is possibly now an ordinary act for Turkish couples which does not make them feel that the communication with their partners is damaged.

\section{CONCLUSION}

A well-functioning relationship both creates healthy families and happy individuals (Coyne et al., 2011: 150). Therefore, it is significant to understand the current problems that couples are having, and those problems are sometimes directly related to the use of technology in daily lives.

This study investigated how pphubbing behavior impacts dating and married couples in Turkey. All three of the hypotheses were rejected. Results demonstrate that pphubbing behavior does not have a negative impact on romantic couples in Turkey. There can be two opposing explanations. The first one if that, the traditional value given especially to the institution of marriage in Turkey might have an affect on couples' declaration of satisfaction or dissatisfaction about their relationships. Even though the survey technique was anonymous, participants might have doubts about giving the right answers about their private lives. The second explanation would be one criticizing most of the studies about phubbing, in claiming that pphubbing is actually a socially accepted act, and does not have that much of a significant negative impact on intimate relationships.

The present study is important for the literature, firstly because understanding the problems of couple relationships has significance in terms of forming healthy families and happy individuals (Coyne et al., 2011: 150), and it is of growing interest to understand how mobile phone use affects intimate relationships. Also, the current study is significant in terms of revealing differences about the impact 
of phubbing behavior on the satisfaction in married and non-married relationships. Another contribution is that, there are no studies conducted on the impact of mobile phones on relationship satisfaction of Turkish couples. Therefore, this study will be useful both to be able to analyze the local situation in Turkey, and also to make a comparative look with studies from other countries in the world. At this point, it is suggested future studies to be done longitudinally, based on observation, and/or qualitatively to reveal more detailed explanations.

\section{REFERENCES}

Abeele, M. V., Schouten, A. P., \& Antheunis, M. L. (2015). The Effect of Mobile Phone Use in Copresent Situations on Impression Formation and Relationship Quality. Annual Conference of the International Communication Association, Abstracts.

Bagarozzi, D.A., Bagarozzi, J.I., Anderson, S.A., \& Pollane, L. (1984). Premarital Education and Training Sequence (PETS): A 3-year Follow-up of an Experimental Study. Journal of Counseling \& Development; 63, pp. 91-100. Doi: 10.1002/j.1556-6676.1984.tb02765.x

Balakrishnan, V., \& Raj, R. G. (2012). Exploring the relationship between urbanized Malaysian youth and their mobile phones: A quantitative approach. Telematics and Informatics, 29(3), pp. 263-272.

Cao, F., \& Su, L. (2007). Internet addiction among Chinese adolescents: prevalence and psychological features. Child: care, health and development, 33(3), pp. 275-281.

Choi, H. S., Lee, H. K., \& Ha, J. C. (2012). The influence of smartphone addiction on mental health, campus life and personal relations-Focusing on K university students. Journal of the Korean Data and Information Science Society, 23(5), pp. 1005-1015.

Clayton, R.B., Nagurney, A., \& Smith, J.R. (2013). Cheating, breakup, and divorce: Is Facebook use to blame? Cyberpsychology, Behavior and Social Networking, 16, pp. 717-720. http://dx.doi.org/10.1089/cyber.2012.0424.

Coyne, S. M., Stockdale, L., Busby, D., Iverson, B., \& Grant, D. M. (2011). "I luv u.)!”: A descriptive study of the media use of individuals in romantic relationships. Family Relations, 60(2), pp. 150-162.

Darvell, M. J., Walsh, S. P., \& White, K. M. (2011). Facebook tells me so: Applying the theory of planned behavior to understand partner-monitoring behavior on Facebook. Cyberpsychology, Behavior and Social Networking, 14, pp. 717-722. http:// dx.doi.org/10.1089/cyber.2011.0035.

Drouin, M., Miller, D.A., Dibble, J.L. (2014). Ignore your partners' current Facebook friend; beware the ones they add! Computers in Human Behavior, 35, pp. 483-488. http://dx.doi.org/10.1016/j.chb.2014.02.032

Dush, C.M.K., Taylor, M.G., \& Kroeger, R.A. (2008). Marital happiness and psychological well being across the life course. Family Relations, 57(2), pp. 211-226.

Ĕgeci, I.S., Gençöz, T. (2006). "Factors Associated with Relationship Satisfaction: Importance of Communication Skills". Contemporary Family Therapy, 28, pp. 383-391. DOI 10.1007/s10591-0069010-2

Elphinston, R. A., \& Noller, P. (2011). Time to face it! Facebook intrusion and the implications for romantic jealousy and relationship satisfaction. Cyberpsychology, Behavior and Social Networking, 14, pp. 631-635. http:// dx.doi.org/10.1089/cyber.2010.0318.

Hall, J. A., Baym, N. K., \& Miltner, K. M. (2014). Put down that phone and talk to me: Understanding the roles of mobile phone norm adherence and similarity in relationships. Mobile Media \& Communication, 2(2), pp. 134-153.

Henline, B. H. (2006). Technology use and intimacy development in committed relationships: Exploring the influence of differentiation of self. Unpublished doctoral dissertation, Texas Tech University, Lubbock, TX.

Hertlein, K. M. (2012). Digital dwelling: Technology in couple and family relationships.

Family Relations, 61, pp. 374-387.

Hertlein, K.M., Blumer, M.L.C. (2014). The Couple and Technology Framework. UK: Routledge.

Hünler, O.S., Gençöz, T. (2005). "The Effect of Religiousness on Marital Satisfaction: Testing the Mediator Role of Marital Problem Solving Between Religiousness and Marital Satisfaction Relationship". Contemporary Family Therapy, 27(1), pp. 123-136. DOI: 10.1007/s10591-004-1974-1 Johansson, A., \& Götestam, K. G. (2004). Internet addiction: characteristics of a questionnaire and prevalence in Norwegian youth (12-18 years). Scandinavian journal of psychology, 45(3), pp. 223229. 
Karadă̆, E., Tosuntaş, Ş.B., Erzen, E., Duru, P., Bostan, N., Şahin, B.M., Çulha, I., \& Babadă̆, B. (2015). "Determinants of Phubbing, which is the sum of many virtual addictions: A structural equation model". Journal of Behavioral Addictions, 4(2), pp. 60-74.

Kim, D., Lee, Y., Lee, J., Nam, J. K., \& Chung, Y. (2014). Development of Korean smartphone addiction proneness scale for youth. PloS one, 9(5), e97920, Retrieved, 09.02.2017: http://journals.plos.org/plosone/article?id=10.1371/journal.pone.0097920

Kim, K., Ryu, E., Chon, M. Y., Yeun, E. J., Choi, S. Y., Seo, J. S., \& Nam, B. W. (2006). Internet addiction in Korean adolescents and its relation to depression and suicidal ideation: a questionnaire survey. International journal of nursing studies, 43(2), pp. 185-192.

Kwon, M., Kim, D. J., Cho, H., \& Yang, S. (2013). The smartphone addiction scale: development and validation of a short version for adolescents. PloS one, 8(12), e83558, Retrieved, 09.02.2017: http://journals.plos.org/plosone/article?id=10.1371/journal.pone.0083558

Leggett, C., Rossouw, P. (2014). "The Impact of Technology Use on Couple Relationships: A Neuropsychological Perspective”. International Journal of Neuropsychotherapy, 2(2), pp. 44-99.

Lenhart, A., \& Duggan, M. (2014). Couples, the internet, and social media. Retrieved: http://www.pewinternet.org/2014/02/11/couples-the-internet-and-social-media/

Ling, R. (2007). Children, youth, and mobile communication. Journal of Children and Media, 1(1), pp. 60-67.

McCormack, M. (2015) 'The role of smartphones and technology in sexual and romantic lives.', Project Report. Durham University, Retrieved: http://dro.dur.ac.uk/14770/1/14770.pdf

McDaniel, B. T., \& Coyne, S. M. (2016). "Technoference”: The interference of technology in couple relationships and implications for women's personal and relational well-being. Psychology of Popular Media Culture, 5(1), pp. 1-24.

Mok, J. Y., Choi, S. W., Kim, D. J., Choi, J. S., Lee, J., Ahn, H., ... \& Song, W. Y. (2014). Latent class analysis on internet and smartphone addiction in college students. Neuropsychiatric disease and treatment, 10, pp. 817-828.

Muise, A., Christofides, E., \& Dermarais, S. (2009). More Information Than You Ever Wanted: Does Facebook Bring Out the Green-Eyed Monster of Jealousy?. CyberPsychology \& Behavior, 12(4), pp. 441-444. doi: $10.1089=c p b .2008 .0263$

Nazir, T., Pişkin, M. (2016). "Phubbing: A Technological Invasion Which Connected the World But Disconnected Humans”. The International Journal of Indian Psychology, 3(4), No: 68, pp. 175-182.

Ofcom, UK now a smartphone society. Retrieved in 08.02.2017: https://www.ofcom.org.uk/aboutofcom/latest/features-and-news/uk-now-a-smartphone-society

Park, N., \& Lee, H. (2014). Nature of Youth Smartphone Addiction in Korea. $\square \square \square \square \square \square$, 51(1), pp. 100-132.

Park, S. K., Kim, J. Y., \& Cho, C. B. (2008). Prevalence of Internet addiction and correlations with family factors among South Korean adolescents. Adolescence, 43(172), pp. 895-909.

Peleg, O. (2008). The relation between differentiation of self and marital satisfaction: What can be learned from married people over the course of life?.The American Journal of Family Therapy, 36(5), pp. 388-401.

Przybylski, A. K., Murayama, K., DeHaan, C. R., \& Gladwell, V. (2013). Motivational, emotional, and behavioral correlates of fear of missing out. Computers in Human Behavior, 29(4), pp. 1841-1848.

Przybylski, A.K., Weinstein, N. (2012). "Can You Connect With me Now? How the Presence of Mobile Communication Technology Influences Face-to-Face Conversation Quality”. Journal of Social and Personal Relationships, pp. 1-10. DOI: 10.1177/0265407512453827

Roberts, J.A., David, M.E. (2016). "My life has become a major distraction from my cell phone: Partner phubbing and relationship satisfaction among romantic partners”. Computers in Human Behavior, 54, pp. 134-141.

Sakalli-Ugurlu, N. (2003). "How Do Romantic Relationship Satisfaction, Gender Stereotypes, and Gender Relate to Future Time Orientation in Romantic Relationships?”. The Journal of Psychology, 137(3), pp. 294-303.

Servies, A. (2012). "Cell Phones and Couple Communication: The Impact of Mobile Device Distractions During a Dyadic Interaction”. Honors Thesis, University of Arkansas. Retrieved: http://scholarworks.uark.edu/cgi/viewcontent.cgi? article $=1000 \&$ context $=$ psycuht 
Tsai, C. C., \& Lin, S. S. (2003). Internet addiction of adolescents in Taiwan: An interview study. CyberPsychology \& Behavior, 6(6), pp. 649-652.

Utz, S., \& Beukeboom, C. J. (2011). The role of social network sites in romantic relationships: Effects on jealousy and relationship happiness. Journal of Computer-Mediated Communication, 16, pp. 511 527. doi:10.1111/j.1083-6101.2011.01552.x

Walsh, S. P., White, K. M., \& Young, R. M. (2008). Over-connected? A qualitative exploration of the relationship between Australian youth and their mobile phones. Journal of adolescence, 31(1), pp. 7792. 